\title{
Implementation of Discovery Learning Model Towards Students Learning Outcome of XI-IPA1 Students on the Respiratory System Materials at Pangsid High School
}

\author{
Akmal Akmal ${ }^{1}$ \\ ${ }^{1}$ SMA Negeri 1 Pangsid, Sidenreng Rappang Regency, Indonesia
}

Receive: 12 April 2019

Accepted: 15 April 2019

Published: 10 Oktober 2019

\begin{abstract}
Tujuan penelitian adalah untuk mengetahui pengaruh penerapan model pembelajaran Discovery Learning terhadap peningkatan hasil belajar siswa kelas XI-IPA1 pada materi sistem pernapasan di SMA Negeri 1 Pangsid Kabupaten Sidenreng Rappang. Penelitian ini dilaksanakan dalam 2 siklus, tiap siklus terdiri dari empat tahapan yaitu: perencanaan, tindakan, observasi dan refleksi. Subyek penelitian adalah siswa kelas XI-IPA1 semester II Tahun 2015/2016 berjumlah 32 orang yang terdiri dari 10 siswa laki-laki dan 22 siswa perempuan. Analisis data dilakukan dengan teknik deskriptif kuantitatif. Hasil penelitian menunjukkan adanya peningkatan hasil belajar siswa pada materi sistem respirasi kelas XIIPA1 SMA Negeri 1 Pangsid. Peningkatan hasil belajar siswa dari skor dasar ke siklus 1 dan siklus II juga mengalami perubahan. Rata-Rata keaktifan siklus I sebesar 22, 68\% meningkat menjadi 77, 32\% pada siklus II. Pencapaian hasil belajar secara klasikal sebesar 93, 8\% Nilai ini sudah melampaui 85\% pada siklus ke II. Kondisi ini menunjukkan hasil belajar siswa dengan kategori sangat tinggi.
\end{abstract}

Kata Kunci: Discovery learning, hasil belajar, sistem pernapasan

\begin{abstract}
This Classroom Action Research (CAR) aims to determine the effect of the implementation of Discovery Learning models towards learning outcome of XI-IPA1 students, on the respiratory system subject matter at SMA 1 Pangsid. This study was conducted in two cycles, each cycle consist of four phases: planning, action, observation and reflection. The subjects were XI IPA 1 student's school year 2015/2016, which is amounted to 32 people, consisting of 10 male students and 22 female students. Data analysis was performed with a descriptive quantitative technique. The results showed an increase in student learning outcomes in the respiratory system materials. Improving student learning outcomes from a base score for cycle 1 and cycle II is also changing. Average activity of in the first cycle is equal to $22,68 \%$, then increased to $77,32 \%$ in the second cycle. Classical learning $93, \% 8$ achievement has exceeded $85 \%$ in the second cycle. This condition shows the results of student learning has high category.
\end{abstract}

Keywords: Discovery Learning Model, learning outcome, respiration system 


\section{Pendahuluan}

Pendidikan mempunyai arti yang sangat penting dalam kehidupan kita, baik dalam kehidupan individu, bangsa maupun negara. Oleh karena itu pendidikan harus dilaksanakan dengan sebaik-baiknya, sehingga sesuai dengan tujuan. Keberhasilan suatu bangsa terletak pada mutu pendidikan yang dapat meningkatkan kualtias sumber daya manusianya. Pendidikan pada dasarnya suatu proses untuk membantu manusia dalam mengembangkan dirinya, sehingga mampu menghadapi segala perubahan dan permasalahan dengan sikap terbuka serta pendekatan -pendekatan yang kreatif tanpa harus kehilangan identitas dirinya. Sekolah merupakan bagian dari sistem pendidikan formal yang mempunyai aturan-aturan jelas atau lebih dikenal dengan GBPP (Garis-garis Besar Program Pengajaran) sebagai acuan proses pembelajaran dan guru sebagai fasilisator yang berperan dalam keberhasilan seorang siswa, sehingga guru harus tepat dalam memilih metode pembelajaran yang akan digunakan.

Pendidikan merupakan usaha sadar yang dilakukan seseorang untuk menjadi pribadi yang lebih baik dan mengembangkan potensi yang dimilikinya agar dapat bermanfaat bagi dirinya sendiri maupun orang lain dalam kehidupannya. Pendidikan bertujuan untuk membantu para siswa dalam mengembangkan potensi yang dimilikinya. Dengan menempuh pendidikan, seseorang dapat terhindar dari rendahnya kemampuan kognitif dan kemiskinan. Pendidikan menjadi pembeda antara seseorang dengan orang yang lainnya, dilihat dari pengetahuan, kemampuan dan keterampilan yang dimilikinya sehingga dapat meningkatkan kesejahteraan. Kemajuan sebuah negara dapat dilihat dari sistem pendidikannya, kualitas pendidikannya, baik dari kualitas tenaga pengajarnya maupun kualitas peserta didiknya. Oleh sebab itu, pendidikan sangat dibutuhkan bagi manusia sebagai proses pengajaran dan pelatihan agar mencapai tujuan tersebut. Proses pengajaran yang baik harus mengacu pada kurikulum yang berlaku. Kurikulum adalah rangkaian rencana isi yang akan menjadi sejumlah tahapan belajar yang didesain untuk siswa dengan petunjuk institusi pendidikan yang isinya berupa proses. Kurikulum yang berlaku di Indonesia saat ini adalah Kurikulum Tingkat Satuan Pendidikan (KTSP). KTSP merupakan salah satu bentuk perkembangan pendidikan yang memberikan kesempatan kepada sekolah dan satuan pendidikan untuk mengembangkan kurikulum sesuai dengan potensi, tuntutan, dan kebutuhan masing-masing. KTSP diterapkan pada satuan pendidikan, dalam praktiknya pendidikan dapat berlangsung dalam lingkungan formal, informal, dan nonformal. Khusus pada pendidikan formal terdapat beberapa jenjang pendidikan di negeri ini yang terdiri dari sekolah dasar (SD), sekolah menengah pertama (SMP), sekolah menengah atas (SMA) dan perguruan tinggi (PT). Proses pembelajaran dari setiap jenjang tersebut tentunya memperhatikan fase perkembangan dan tingkat kemampuan setiap peserta didik seperti kognitif, psikomotor dan afektif.

Biologi merupakan salah satu cabang ilmu IPA yang berperan sangat esensial dalam perkembangan sains dan teknologi. Oleh karena itu, siswa dituntut untuk menguasai materi pelajaran biologi secara tuntas. Biologi berkaitan dengan cara mencari tahu tentang alam secara sistematis, sehingga biologi bukan hanya sebagai penguasaan kumpulan pengetahuan yang berupa fakta-fakta, konsep-konsep atau prinsip-prinsip saja, tetapi juga merupakan suatu proses penemuan. Pendidikan biologi di sekolah menengah diharapkan dapat menjadi wahana bagi peserta didik untuk mempelajari diri sendiri dan alam sekitar, serta prospek pengembangan lebih lanjut dalam menerapkannya di dalam kehidupan seharihari. Pendidikan biologi menekankan pada pemberian pengalaman langsung untuk mengembangkan kompetensi agar peserta didik menjelajahi dan memahami alam sekitar secara ilmiah. Pendidikan biologi diarahkan untuk mencari tahu dan berbuat sehingga dapat membantu peserta didik untuk memperolehpemahaman yang lebih mendalam tentang dirinya sendiri dan alam sekitarKeberhasilan pengajaran biologi ini 
ditentukan oleh besarnya partisipasi siswa dalam mengikuti pembelajaran, makin aktif siswa mengambil bagian dalam kegiatan pembelajaran, maka makin berhasil kegiatan pembelajaran tersebut. Tanpa aktivitas belajar tidak akan memberikan hasil yang baik (Rustaman, 2005). Pada kenyataannya, guru dalam melakukan kegiatan belajar mengajar di kelas cenderung berlangsung secara konvensional atau menggunakan strategi pembelajaran tradisional. Artinya guru mentransformasi ilmu pengetahuannya dengan menggunakan metode ceramah sehingga pembelajaran berpusat pada guru (teacher centered). Padahal menurut KTSP, kegiatan belajar mengajar harus berpusat pada siswa yang artinya siswa harus lebih aktif menggali informasi sendiri. Selain itu, kenyataan dilapangan menunjukkan bahwa pencapaian jumlah siswa yang tuntas belajar di SMA Negeri 1 Pangsid Kabupaten Sidenreng Rappang kelas XI-IPA1 ternyata masih rendah. Dikatakan rendah karena belum mencapai Kriteria Ketuntasan Minimal (KKM) yang telah ditetapkan di sekolah tersebut untuk pelajaran biologi yaitu $\geq 75$.

Kondisi pembelajaran biologi seperti ini akan menimbulkan kebosanan bagi siswa, siswa tidak dapat melihat hubungan antar materi pelajaran yang telah dipelajari dengan materi berikutnya, ini diperparah dengan sikap guru yang tidak pernah mengingatkan kembali siswa tentang hal tersebut dan terus melanjutkan materi tanpa mamperhatikan apakah siswa pada umumnya telah memahami materi yang diberikan sehingga pelajaran biologi menjadi tidak menarik, tidak disenangi, dan dengan sendirinya pelajaran biologi akan terasa membosankan. Dengan demikian sebagai konsekuensinya, hasil belajar yang dicapai siswa belum sesuai dengan harapan. Untuk mengatasi masalah tersebut di atas, perlu diupayakan suatu metode pembelajaran yang dapat digunakan untuk membuat pembelajaran lebih aktif. Salah satunya adalah dengan menerapkan model pembelajaran discovery learning (penemuan). Model pembelajaran discovery learning adalah model mengajar yang mengatur pengajaran sedemikian rupa sehingga anak memperoleh pengetahuan yang sebelumnya belum diketahuinya itu tidak melalui pemberitahuan, sebagian atau seluruhnya ditemukan sendiri. Dalam pembelajaran discovery kegiatan atau pembelajaran yang dirancang sedemikian rupa sehingga siswa dapat menemukan konsep-konsep dan prinsip-prinsip melalui proses mentalnya sendiri. Dalam menemukan konsep, siswa melakukan pengamatan, menggolongkan, membuat dugaan, menjelaskan, menarik kesimpulan dan sebagainya untuk menemukan beberapa konsep atau prinsip (Suherman, 2011).

Menurut pandangan konstruktivisme, belajar adalah proses aktif siswa dalam mengonstruksi arti, wacana, dialog, dan pengalaman fisik dimana di dalamnya terjadi proses asimilasi dan menghubungkan pengalaman atau informasi yang sudah dipelajari (Rifa'i \& Anni, 2011). Dalam pembelajaran discovery learning siswa tidak diberikan konsep dalam bentuk finalnya, melainkan siswa diajak untuk ikut serta dalam menemukan konsep tersebut. Siswa membangun pengetahuan berdasarkan informasi baru dan kumpulan data yang mereka gunakan dalam sebuah pembelajaran penyelidikan (De Jong \& Joolingen, 1998). Keikutsertaan menemukan konsep dalam pembelajaran memberikan kesan yang lebih mendalam kepada siswa sehingga informasi disimpan lebih lama dalam memori para siswa. Proses menemukan sendiri konsep yang dipelajari juga memberikan motivasi kepada siswa untuk melakukan penemuanpenemuan lain sehingga minat belajarnya semakin meningkat. Materi sistem pernapasan pada manusia merupakan salah satu materi biologi yang erat hubungannya dengan kehidupan. Biologi merupakan pengetahuan teoritis yang diperoleh atau disusun dengan cara yang khas atau khusus, yaitu dengan melakukan observasi, eksperimentasi, penyimpulan, penyusunan teori, eksperimentasi, dan observasi.

Oleh karena itu, penggunaan Model pembelajaran discovery learning dalam pembelajaran biologi khususnya pada materi sistem pernapasan pada manusia diharapkan dapat membantu siswa dalam menemukan ide-ide baru, demi memperbaiki prestasi 
belajar siswa khususnya pada mata pelajaran biologi. Berdasarkan paparan di atas penulis bermaksud mencoba inovasi baru dalam pembelajaran biologi melalui penerapan model pembelajaran discovery learning dengan harapan hasil belajar siswa SMA Negeri 1 Pangsid Kabupaten Sidenreng Rappang meningkat.

\section{Metode}

1. Jenis dan Desain Penelitian Jenis penelitian ini adalah penelitian tindakan kelas (PTK) yang dilakukan di kelas melalui kegiatan pembelajaran dengan menggunakan model pembelajaran Discovery Learning. Penelitian Tindakan Kelas bertujuan adalah untuk mengetahui peningkatan hasil belajar siswa kelas XI-IPA1 melalui penerapan model pembelajaran Discovery Learning. pada materi sistem pernapasan di SMA Negeri Pangsid Kabupaten Sidenreng Rappang. Target penelitian adalah siswa SMA Negeri 1 Pangsid Kabupaten Sidenreng Rappang kelas X1-IPA1 semester genap tahun pelajaran 2015/2016 pada materi sistem pernapasan. Penelitian dilaksanakan pada bulan september sampai dengan bulan desember Tahun 2016. Subyek penelitian adalah siswa kelas X1 -IPA1 dengan jumlah siswa sebanyak 32 orang yang terdiri dari 10 orang siswa laki-laki dan 22 orang siswa perempuan.

Penelitian ini merupakan Penelitian Tindakan Kelas (PTK) yang dilaksanakan dalam 2 siklus. Masing-masing siklus terdiri atas empat tahapan, yaitu: perencanaan, tindakan, observasi dan refleksi. Data yang diperlukan adalah data mengenai aktivitas siswa selama proses pembelajaran serta data tentang tes hasil belajar siswa setelah proses pembelajaran. Teknik pengumpulan data dengan menggunakan lembar pengamatan dan tes. Data dianalisis dengan menggunakan analisis deskriptif yang bertujuan untuk mendeskripsikan data hasil belajar siswa selama proses pembelajaran.

\section{Teknik Analisis Data}

a) Aktivitas Siswa

Lembar observasi keaktifan siswa ini untuk melihat keaktifan dalam pembelajaran. Indikator keaktifan siswa dalam pembelajaran berupa keaktifan siswa dalam bertanya, berpendapat, menjawab pertanyaan, berpresentasi dan menyimpulkan pembelajaran. Analisis data keaktifan siswa yaitu dengan menghitung rata-rata keaktifan siswa dalam setiap pembelajaran, dengan rumus sebagai

$$
X=\Sigma \frac{X}{n}
$$

Keterangan:

$\bar{X}_{-}=$Rata-rata keaktifan

$\sum x a=$ Jumlah siswa aktif

$\mathrm{n}=$ Jumlah aspek

I. Kesiapan siswa

Lembar observasi kesiapan siswa ini digunakan untuk melihat apakah siswa telah siap dalam memulai pembelajaran. Kesiapan siswa diukur dengan apakah siswa membawa buku paket, buku referensi lain, buku catatan dan alat-alat tulis dalam belajar. Analisis data kesiapan siswa dengan menghitung rata-rata kesiapan siswa setiap pembelajaran, dengan rumus sebagai berikut (Depdiknas).

$$
X=\Sigma \frac{X}{n}
$$

Keterangan:

$\bar{X}_{-}=$Rata-rata kesiapan

siswa $\sum x s=$ Jumlah siswa yang

siap

$\mathrm{n}$ = Jumlah aspek

c) Data hasil belajar

Kriteria ketuntasan hasil belajar mengacu pada kriteria ketuntasan minimum mata pelajaran biologi di SMA Negeri 1 Pangsid Kabupaten Sidenreng Rappang yaitu 70. Untuk mengetahui presentase ketuntasan hasil belajar siswa selama pembelajaran dengan menggunakan model pembelajaran Discovery, maka digunakan rumus presentase (Anas Sudijono, 2005) adalah 


$$
P=\frac{f}{N} \times 100 \%
$$

Keterangan :

$P=$ Angka persentase

$f=$ Frekuensi siswa yang

tuntas $N=$ Jumlah siswa

Kriteria ketuntasan belajar yang digunakan seperti dikemukakan Aqib (Rahmayanti, 2012,) seperti tertera dalam tabel berikut.

Tabel 1. Kriteria ketuntasan belajar siswa

\begin{tabular}{c|l}
\hline Persentase (\%) & \multicolumn{1}{|c}{$\begin{array}{c}\text { Kategori } \\
\text { Penilaian }\end{array}$} \\
\hline$>80 \%$ & Sangat Tinggi \\
\hline $75-79,9 \%$ & Tinggi \\
\hline $70-74,9 \%$ & Cukup \\
\hline $60-69,9 \%$ & Rendah \\
$0-59,9 \%$ & Sangat Rendah \\
\hline i posisinya).
\end{tabular}

\section{Hasil danPembahasan}

Kondisi Awal (Pra Siklus)

Kondisi awal (pra siklus) hasil belajar siswa kelas X1-IPA1 SMA Negeri 1 Pangsid Kabupaten Sidenreng Rappang pada materi sistem pernapasan diperoleh dengan cara memberikan tes kemampuan awal (pretest), yang bertujuan untuk mengetahui kemampuan siswa sebelum diterapkan model pembelajaran Discovery Learning. Adapun hasil belajar siswa sebelum tindakan diberikan (pra siklus) dapat dilihat pada tabel 2 .

Tabel 2. Deskripsi Kondisi Awal (Pra Siklus) Jumlah Ketuntasan

\begin{tabular}{l|c|c}
\hline Klasifikasi & Frekuensi & $\begin{array}{c}\text { Persentase } \\
\text { (\%) }\end{array}$ \\
\hline Tuntas & 4 & 12,5 \\
\hline $\begin{array}{l}\text { Tidak } \\
\text { tuntas }\end{array}$ & 28 & 87,5 \\
\hline Total & 32 & 100 \\
\hline
\end{tabular}

Dari Tabel 2 terlihat bahwa terdapat $28(87,5 \%)$ peserta didik yang tidak tuntas, dan $4(12,5 \%)$ yang tuntas. Hal ini menunjukkan bahwa kondisi awal (pra siklus) sebelum penerapan model pembelajaran Discovery Learning. Ketuntasan belajar siswa masih sangat rendah, sehingga berpatokan pada hasil observasi tersebut maka dirasa perlu untuk melakukan tindakan dengan menerapkan model pembelajaran discovery learning.

Siklus 1

Berdasarkan hasil observasi selama penelitian dilakukan pada siklus 1 diperoleh gambaran terjadinya perubahan dalam proses pembelajaran, walaupun aktifitas siswa masih kurang lancar. Siswa masih kurang aktif dalam berdiskusi. Data tentang aktifitas siswa selama proses pembelajaran pada siklus I diperoleh melalui observasi yang dilakukan oleh seorang guru biologi yang berperan sebagai pengamat. Pada tahap ini pengamat mengamati setiap kejadian yang berlangsung ketika proses pelaksanaan tindakan yang dilakukan oleh peneliti, sambil melakukan pengamatan ini pengamat mengisi lembar observasi kegiatan siswa pada proses kegiatan belajar mengajar. Hasil observasi aktivitas siswa dapat dilihat pada tabel 3.

Tabel 3. Hasil Observasi Keaktifan Siswa Siklus 1

\begin{tabular}{|c|c|c|c|}
\hline \multirow[t]{2}{*}{ NO } & \multirow{2}{*}{$\begin{array}{l}\text { Aspek yang } \\
\text { diamati }\end{array}$} & \multicolumn{2}{|l|}{ Siklus } \\
\hline & & Aktif & $\begin{array}{l}\text { Tidak } \\
\text { Aktif }\end{array}$ \\
\hline 01 & $\begin{array}{l}\text { Aktivitas siswa } \\
\text { mengkomunika } \\
\text { sikan masalah }\end{array}$ & $\begin{array}{l}4 \\
(12,5 \%)\end{array}$ & $\begin{array}{l}28 \\
(87,5 \\
\%)\end{array}$ \\
\hline 02 & $\begin{array}{l}\text { Aktifitas siswa } \\
\text { dalam bertanya }\end{array}$ & $\begin{array}{l}14 \\
(43,8 \%)\end{array}$ & $\begin{array}{l}18 \\
(56,2 \\
\%)\end{array}$ \\
\hline 03 & $\begin{array}{l}\text { Aktivitas siswa } \\
\text { dalam } \\
\text { menjawab } \\
\text { Pertanyaan } \\
\text { Guru }\end{array}$ & $\begin{array}{l}10 \\
(32 \%)\end{array}$ & $\begin{array}{l}22 \\
(68,8 \\
\%)\end{array}$ \\
\hline 04 & $\begin{array}{l}\text { Aktifitas siswa } \\
\text { dalam } \\
\text { berpendapat }\end{array}$ & $8(16)$ & $\begin{array}{l}24 \\
(75 \%)\end{array}$ \\
\hline 05 & $\begin{array}{l}\text { Aktivitas siswa } \\
\text { dalam }\end{array}$ & $7(20 \%)$ & $\begin{array}{l}25 \\
(78,2\end{array}$ \\
\hline
\end{tabular}




\begin{tabular}{l|l|l|l}
\hline & $\begin{array}{l}\text { menyusun } \\
\text { kesimpulan }\end{array}$ & $\%)$ \\
\hline 06 & $\begin{array}{l}\text { Aktivitas siswa } \\
\text { dalam } \\
\text { menyusun } \\
\text { Rangkuman }\end{array}$ & $8(16 \%)$ & $\begin{array}{l}24 \\
(75 \%)\end{array}$ \\
\hline & Rata- rata & $\begin{array}{l}8,5 \\
(26,55\end{array}$ & $\begin{array}{l}23,5(7 \\
5,45 \% \\
1\end{array}$ \\
\hline
\end{tabular}

Berdasarkan data di atas dapat disimpulkan bahwa selama kegiatan pembelajaran, siswa kurang aktif, karena tingkat keaktifan siswa masih di bawah 35 $\%$. Prosentase siswa yang tidak aktif adalah $7455, \%$ dan siswa yang aktif 26,55 \%. Ini dikarenakan dalam pembelajaran, yang aktif didominasi oleh ketua kelompok saja serta siswa malu dan takut untuk bertanya kepada guru dan pada anggota kelompoknya. Ada juga siswa yang ngobrol saja, ini disebabkan karena ketua kelompok ada yang tidak melakukan pembagian tugas pada anggotanya. Ketidakaktifan terjadi karena mereka belum terbiasa dengan kelompok yang baru dan pembelajaran metode Discovery Learning sehingga pada siklus I tingkat keaktifan siswa belum tercapai.

\section{a. Hasil observasi kesiapan siswa}

Data hasil observasi ini digunakan untuk mengetahui kesiapan siswa mengikuti pembelajaran. Data tentang kesiapan siswa mengikuti pembelajaran pada siklus I diperoleh melalui observasi, dan hasilnya dapat dilihat pada tabel 4.

Tabel 4. Hasil Observasi Kesiapan Siswa Siklus I

\begin{tabular}{l|l|l|l|l}
\hline No & Aspek Yang & \multicolumn{2}{|l|}{ Siklus } & Total \\
\cline { 2 - 4 } & Diamati & Ya & Tidak & \\
\hline 1 & $\begin{array}{l}\text { Membawah } \\
\text { Buku Paket } \\
\text { Biologi }\end{array}$ & 28 & 4 & 32 \\
\hline 2 & $\begin{array}{l}\text { Buku refrensi } \\
\text { lain Yang relefan }\end{array}$ & 5 & 27 & 32 \\
\hline 3 & $\begin{array}{l}\text { Membawah } \\
\text { Buku Catatan } \\
\text { Biologi }\end{array}$ & 32 & - & 32 \\
\hline
\end{tabular}

\begin{tabular}{l|l|l|l|l}
\hline 4 & $\begin{array}{l}\text { Membawah } \\
\text { Kelengkapan } \\
\text { alat tulis }\end{array}$ & 26 & 6 & 32 \\
\hline & Total & 91 & 37 & 128 \\
\hline & Rata-rata & 22,8 & 9,2 & \\
\hline
\end{tabular}

Pada data di atas dapat dilihat bahwa tidak semua siswa siap menerima pembelajaran karena masih ada 4 siswa belum membawa buku paket, 27 siswa belum membawa buku referensi lain, semua siswa belum membawa buku catatan biologi dan 6 siswa belum membawa kelengkapan alat tulis. Kesiapan siswa secara keseluruhan menunjukkan rata-rata 22,8 dan 9,2 Siswa belum siap menerima pelajaran. Untuk mengatasi hal ini, siswa yang belum siap menerima pelajaran dicatat dan siswa yang bersangkutan diberi kesempatan bekerja dalam kelompoknya dengan bantuan anggota kelompok masingmasing.

b. Hasil tes

Berdasarkan hasil tes yang dilakukan, tidak terlalu terjadi peningkatan, hanya beberapa orang siswa yang tuntas dalam belajar. Gambaran hasil tes pada siklus I dapat dilihat dalam tabel 5.

Tabel 5. Persentase ketuntasan belajar siswa siklus I

\begin{tabular}{l|ll|l}
\hline \multirow{2}{*}{ No } & Perolehan Siswa & \multicolumn{2}{l}{ Siklus } \\
\cline { 3 - 4 } & & Total & $\begin{array}{l}\text { Persentase } \\
(\%)\end{array}$ \\
\hline 1 & $\begin{array}{l}\text { Persentase } \\
\text { siswa yang } \\
\text { tuntas Belajar }\end{array}$ & 14 & 43,8 \\
\hline 2 & $\begin{array}{l}\text { Persentase } \\
\text { siswa yang } \\
\text { belum tuntas } \\
\text { belajar }\end{array}$ & $18 \cdot 56,2$ \\
\hline
\end{tabular}

c. Refleksi

Setelah pelaksanaan siklus pertama dilalui dengan tiga kali pertemuan maka tidak begitu terlihat adanya peningkatan hasil belajar. Kendala yang ditemui pada siklus ini 
adalah penggunaan waktu yang kurang efektif dan kesiapan belajar siswa yang kurang serta siswa belum terbiasa belajar dengan suasana kelas yang baru. Berdasarkan kendala-kendala pada siklus I di atas, langkah selanjutnya adalah melakukan perbaikan untuk siklus II. Penulis harus merencanakan dengan baik dan mempersiapkan segalanya agar kekurangan-kekurangan pada siklus I dapat diperbaiki. sendiri dan siswa dapat melakukan presentasi dengan baik dan mempersiapkan segalanya agar kekurangankekurangan pada siklus I tidak terjadi lagi pada siklus II.

Siklus ke-2

a. Hasil observasi keaktifan siswa

Data tentang aktifitas siswa selama proses pembelajaran diperoleh melalui observasi, dan hasilnya dapat dilihat pada tabel 6.

Tabel 6. Hasil Observasi Keaktifan Siswa Siklus II

\begin{tabular}{|c|c|c|c|c|}
\hline \multirow[t]{2}{*}{ No } & \multirow{2}{*}{$\begin{array}{l}\text { Aspek Yang } \\
\text { Diamati }\end{array}$} & \multicolumn{2}{|l|}{ Siklus } & \multirow{2}{*}{$\begin{array}{l}\text { Tot } \\
\text { al }\end{array}$} \\
\hline & & Aktif & Tidak & \\
\hline 1 & $\begin{array}{l}\text { Aktivitas } \\
\text { Siswa } \\
\text { Mengkomunik } \\
\text { asikan } \\
\text { masalah } \\
\end{array}$ & $\begin{array}{l}22(68, \\
7 \%)\end{array}$ & $\begin{array}{l}\text { 10(31, } \\
3 \%)\end{array}$ & 32 \\
\hline 2 & $\begin{array}{l}\text { Aktivitas } \\
\text { Siswa Dalam } \\
\text { Bertanya }\end{array}$ & $\begin{array}{l}27(84,7 \\
\%)\end{array}$ & $\begin{array}{l}5(15,6 \\
\%)\end{array}$ & 32 \\
\hline 3 & $\begin{array}{l}\text { Aktivitas } \\
\text { Siswa Dalam } \\
\text { Menjawab } \\
\text { Pertanyaan } \\
\text { Guru }\end{array}$ & $\begin{array}{l}28(88,5 \\
\%)\end{array}$ & $\begin{array}{l}4(12,5 \\
\%)\end{array}$ & 32 \\
\hline 4 & $\begin{array}{l}\text { Aktivitas } \\
\text { Siswa Dalam } \\
\text { Berpendapat }\end{array}$ & $\begin{array}{l}20(62,5 \\
\%)\end{array}$ & $\begin{array}{l}12(37,5 \\
\%)\end{array}$ & 32 \\
\hline 5 & $\begin{array}{l}\text { Aktivitas } \\
\text { Siswa Dalam } \\
\text { Menyusun } \\
\text { Kesimpulan }\end{array}$ & $\begin{array}{l}15(46,8 \\
\%)\end{array}$ & $\begin{array}{l}17(53,7 \\
\%)\end{array}$ & 32 \\
\hline 6 & $\begin{array}{l}\text { Aktivitas } \\
\text { Siswa Dalam } \\
\text { Menyusun } \\
\text { Rangkuman }\end{array}$ & $\begin{array}{l}32(100 \\
\%)\end{array}$ & - & 32 \\
\hline & Tota & 149 & 53 & 32 \\
\hline
\end{tabular}

\begin{tabular}{l|lll}
\hline Rata & $75,2 \%$ & $24,68 \%$ & 192 \\
\hline
\end{tabular}

Dari tabel di atas dapat diketahui bahwa pada siklus II aktivitas siswa dalam proses pembelajaran semakin membaik dan meningkat. Kondisi ini ditandai oleh jumlah siswa yang aktif $75,32 \%$ dan siswa yang tidak aktif dalam pembelajaran yaitu $24,68 \%$. Hal ini dikarenakan siswa sudah memiliki keberanian untuk mengungkapkan pendapat, bertanya dan menjawab pertanyaan guru dengan keinginan sendiri dan siswa dapat melakukan persentasi dengan baik.

\section{Hasil observasi kesiapan siswa}

Pada siklus II ini kesiapan siswa dalam memulai pembelajaran sudah meningkat. Data tentang hasil kesiapan siswa dalam pembelajaran dapat dilihat pada tabel 7.

Tabel 7. Hasil Observasi Kesiapan Siswa Siklus II

\begin{tabular}{c|l|c|c}
\hline No & \multirow{2}{*}{ Aspek yang diamati } & \multicolumn{2}{|c}{ Siklus II } \\
\cline { 3 - 4 } & & Ya & Tidak \\
\hline 1 & $\begin{array}{l}\text { Membawa buku } \\
\text { paket biolog i }\end{array}$ & 32 & - \\
\hline 2 & $\begin{array}{l}\text { Buku refrensi lain } \\
\text { yang relevan }\end{array}$ & 32 & - \\
\hline 3 & $\begin{array}{l}\text { Membawa buku } \\
\text { catatan biolog i }\end{array}$ & 32 & - \\
\hline 4 & $\begin{array}{l}\text { Membawa } \\
\text { kelengkapan alat tulis }\end{array}$ & 32 & - \\
\hline & Jumlah & 128 & - \\
\hline & Rata-rata & 32 & - \\
\hline
\end{tabular}

Berdasarkan data pada tabel 7 dapat disimpulkan bahwa semua siswa telah siap menerima pelajaran. Tidak ada lagi siswa yang lupa membawa buku paket biologi, buku referensi lain, buku catatan dan alat tulis. Keadaan ini menunjukkan bahwa siswa telah terbiasa mempersiapkan diri sebelum memulai belajar. Kebiasan ini diperoleh 
setelah beberapa siswa yang melanggar dikenakan sanksi yaitu hafalan.

b. Hasil tes

Berdasarkan hasil tes yang dilakukan, sudah terjadi peningkatan. Gambaran hasil tes pada siklus II dapat dilihat pada tabel 8.

Tabel 8. Persentase ketuntasan belajar siswa pada siklus II

\begin{tabular}{|l|l|l|l|}
\hline No & $\begin{array}{l}\text { Perolehan } \\
\text { Siswa }\end{array}$ & \multicolumn{2}{|l|}{ Siklus } \\
\cline { 2 - 4 } 1 & $\begin{array}{l}\text { Total } \\
\text { Persentase } \\
\text { siswa yang } \\
\text { tuntas Belajar }\end{array}$ & $\begin{array}{l}\text { Persentase } \\
(\%)\end{array}$ \\
\hline 2 & $\begin{array}{l}\text { Persentase } \\
\text { siswa yang } \\
\text { belum tuntas } \\
\text { belajar }\end{array}$ & 2 & 93,8 \\
\hline & Total & 32 & 100 \\
\hline
\end{tabular}

Ketuntasan suatu kelas dalam belajar secara klasikal pada tiap siklus untuk lebih lengkapnya dapat dilihat dalam tabel 9.

Tabel 9. Ketuntasan Secara Klasikal Siswa

\begin{tabular}{|l|l|l|l|l|l|}
\hline N & \multirow{2}{*}{$\begin{array}{l}\text { Ketuntas } \\
\text { an }\end{array}$} & \multicolumn{2}{|l|}{ Frekuensi } & \multicolumn{2}{l|}{$\begin{array}{l}\text { Persentase } \\
(\%)\end{array}$} \\
\cline { 3 - 6 } & & $\begin{array}{l}\text { Siklu } \\
\text { s 1 }\end{array}$ & $\begin{array}{l}\text { Siklu } \\
\text { s II }\end{array}$ & $\begin{array}{l}\text { Siklu } \\
\text { s 1 }\end{array}$ & $\begin{array}{l}\text { Siklu } \\
\text { s II }\end{array}$ \\
\hline 1 & Tuntas & 14 & 30 & 43,8 & 93,8 \\
\hline 2 & $\begin{array}{l}\text { Tidak } \\
\text { Tuntas }\end{array}$ & 18 & 2 & 56,2 & 6,2 \\
& Total & 32 & 32 & 100 & 100 \\
\hline
\end{tabular}

c. Refleksi

Pada proses pembelajaran dalam siklus II, sudah terjadi perubahan yang diharapkan pada diri siswa. Dimana siswa aktif dalam proses belajar -mengajar yang sebelumnya lebih banyak diam (pasif). Selain itu hasil belajar siswa sudah optimal, yaitu 93,8 \% siswa sudah tuntas belajar. Aktivitas dan hasil belajar siswa yang sudah optimal ini sudah sesuai dengan indikator keberhasilan dimana $>85 \%$ siswa aktif dalam kegiatan belajar-mengajar dan $>75 \%$ siswa tuntas belajar. Peningkatan hasil belajar siswa kelas XI-IPA1 pada materi sistem pernapasan di SMA Negeri 1 Pangsid Kabupaten Sidenreng Rappang dapat ditingkatkan dengan menggunakan model pemelajaran Discovery learning . Hasil observasi tahap awal (pra siklus) diketahui bahwa siswa yang tuntas belajar hanya $12 \%$, siklus I sebesar $43,8 \%$ sedangkan pada akhir siklus II diperoleh $93,8 \%$

Tabel 10. Perbandingan Ketuntasan Peserta Didik

\begin{tabular}{|l|l|l|l|}
\hline N & Siklus & $\begin{array}{l}\text { Persentase(\% } \\
\text { ) }\end{array}$ & $\begin{array}{l}\text { Keteranga } \\
\mathrm{n}\end{array}$ \\
\hline 1 & $\begin{array}{l}\text { PraSiklu } \\
\text { s }\end{array}$ & 12,5 & $\begin{array}{l}\text { Sangat } \\
\text { Rendah }\end{array}$ \\
\hline 2 & Siklus 1 & 43,8 & Rendah \\
\hline 3 & Siklus II & 93,8 & $\begin{array}{l}\text { Sangat } \\
\text { Tinggi }\end{array}$ \\
\hline \multicolumn{3}{|c|}{ Terjadi Peningkatan (Meningkat) } \\
\hline
\end{tabular}

\section{Simpulan}

Penelitian ini memberikan kesimpulan sebagai berikut:

1. Penerapan model pembelajaran penemuan (Discovery Learning) dapat meningkatkan hasil belajar siswa dari skor dasar ke siklus 1 dan siklus II mengalami perubahan. Rata-Rata keaktifan siklus I sebesar $22,67 \%$ meningkat menjadi $75,32 \%$ pada siklus II.

2. Peningkatan Jumlah siswa yang memenuhi KKM (Kriteria Ketuntasan Minimal) bertambah dari 4 (12,5\%), orang menjadi $23(43,8 \%)$ orang dan 30 $(93,8 \%)$ orang siswa.

3. Peningkatan hasil belajar siswa pada materi sistem respirasi kelas X1-IPA1 SMA Negeri 1 Pangsid Kabupaten Sidenreng Rappang melalui Pencapaian 
hasil belajar secara klasikal sudah melampaui $85 \%$ pada siklus ke II. Kondisi ini menunjukkan hasil belajar siswa telah berkategori sangat tinggi.

\section{DaftarPustaka}

[1] Anam, Khoirul. 2016. Pembelajaran Berbasis Inkuiri Metode Dan Aplikasi. Yogyakarta :Pustaka Pelajar.

[2] Arikunto, S \&Safruddin C. 2009. EvaluasiProgram Pendidikan. Jakarta : Bumi Aksara.

[3] Aryulina, D., dkk. (2007). Biologi 2 SMA dan MA untuk kelas XI. Esis. Jakarta: Erlangga

[4] Badan Penelitian dan Pengembangan Departemen Pendidikan Nasional. 2006. Kebijakan Pusat Kurikulum

[5] Depdiknas. (2003). Pendekatan kontekstual (Contextual teaching and learning: CTL). Jakarta: Ditjen Dikdasmen.

[6] Hariyanto, S. 2011. Belajar dan Pembelajaran. Surabaya: PT Remaja Rosdakarya.

[7] Hosnan, M. 2014. Pendekatan Saintifik dan Kontekstual Dalam Pembelajaran Abad 21. Bogor: Ghalia Indonesia

[8] Kurniasih, I \& Sani Be. 2014. Sukses Mengimplementasikan Kurikulum 2013: Memahami berbagai aspek dalam kurikulum 2013. Yogyakarta: Kata Pena
[9] Nasution. (2005). Berbagai pendekatan dalam proses belajar mengajar. Jakarta: Bumi Aksara

[10] Nuryani, R. (2005). Strategi belajar mengajar biologi. Malang: Universitas Negeri Malang

[11] Rusman, $2014 . \quad$ Model-model Pembelajaran Mengembangkan Profesional Guru. Jakarta: Rajawali Press.

[12] Saiful, M. (2002). Psikologi pendidikan. Jakarta: Rineka Cipta.

[13] Sardiman, A.M. (2012). Interaksi \& Motivasi Belajar Mengajar. Jakarta: Rajawali Press.

[14] Sumarno, Alim, dan Ngalimun. 2011. Strategi Pembelajaran Berorientasi Standar Proses. Yogyakarta: Pustaka Pelajar

[15] Sudjana, N. (2004). Penilaian hasil proses belajar mengajar. Bandung: Remaja Rosda Karya.

[16] Ismail, I., Elihami, E., \& Mustakim, M. (2019). Students' Perceptions of the Benefits of Mobile Polling Technology in Teaching and Learning in College: Implications of Students' Participation and academic Performance. Jurnal Pendidikan Progresif, 9(1), 89-104.

[17] Sukidin, dkk. (2008). Manajemen Penelitian Tindakan Kelas. Jakarta: Insan Cendikia

[18] Trianto. 2007. Model Pembelajaran Terpadu Dalam Teori Dan Praktek. Jakarta: Prestasi Pustaka Publisher 